University of Warwick institutional repository: http://go.warwick.ac.uk/wrap This paper is made available online in accordance with publisher policies. Please scroll down to view the document itself. Please refer to the repository record for this item and our policy information available from the repository home page for further information.

To see the final version of this paper please visit the publisher's website. Access to the published version may require a subscription.

Author(s): A.P. Simester and Winnie Chan

Article Title: INDUCING BREACH OF CONTRACT: ONE TORT OR TWO?

Year of publication: 2004

Link to published

version: http://dx.doi.org/10.1017/S0008197304006531

Publisher statement: None 


\section{INDUCING BREACH OF CONTRACT: ONE TORT OR TWO?}

\section{A.P. Simester AND WinNie Chan*}

IT is said to be a tort for D intentionally to induce C to break C's contract with $\mathrm{P}$. Where this occurs, $\mathrm{P}$ has an action in tort against $\mathrm{D},{ }^{1}$ quite apart from P's action for breach of contract against $\mathrm{C}$. $^{2}$ But the rationale for this tort is controversial, and its legitimacy has been doubted by a number of commentators. ${ }^{3}$ Indeed, it is uncertain whether the tort has just one rationale-and if so, whether that is merely an instance of the wider rationale underpinning a generic tort, of intentionally causing harm by unlawful means, as Tony Weir has claimed. ${ }^{4}$ Consider the following scenarios:

Case 1 (persuasion): $\mathrm{C} 1$, a singer, has contracted with $\mathrm{P} 1$, a promoter, to sing exclusively for $\mathrm{P} 1$. D1, a rival promoter, offers $\mathrm{C} 1$ a contract to sing instead for D1. C1 agrees to sing for D1.

Case 2 (prevention): C2, a car manufacturer, has contracted with P2, a tyre manufacturer, to display P2's tyres on C2's cars while the cars are being exhibited at a motor show. During the show D2, a rival, removes P2's tyres without permission and replaces them with its own.

These scenarios may be regarded as paradigm methods of inducing a breach of contract. If one is successfully to analyse and justify that tort, it is necessary to identify the morally salient features of these paradigms, and explain how those features provide reasons why the state should intervene on P's behalf through the law of tort. As part of that process, the question needs to be resolved whether

* Respectively, Professor of Legal Philosophy, University of Nottingham and Lecturer in Law, University of Warwick. We are grateful for valuable comments from Antony Duff, Andrew von Hirsch, Michael Prichard, Paul Roberts, Craig Rotherham, and Christian Witting.

1 Lumley v. Gye (1853) 2 E. \& B. 216, 118 E.R. 749, confirmed in Allen v. Flood [1898] A.C. 1.

2 Cf. Lumley v. Wagner (1852) 1 De G. M. \& G. 604, 42 E.R. 687.

${ }^{3}$ See, e.g., D. Howarth, Textbook on Tort (London 1995), 484 ("Lumley v. Gye was wrongly decided"); Dan D. Dobbs, "Tortious Interference with Contractual Relationships" (1980) 34 Ark. L. Rev. 335, 345 (lamenting "the complete absence of any principle that will explain to us what judgments to make and why it is that liability sometimes is and sometimes is not imposed"); Lyn L. Stevens, "Interference with Economic Relations-Some Aspects of the Turmoil in the Intentional Torts" (1974) 12 Osgoode Hall L.J. 595, 595 ("illogical and piecemeal").

4 Economic Torts (Oxford 1997), 28. 
these scenarios present one paradigm or two. Are there, in truth, two different species of the tort of inducing breach of contract, or are these scenarios merely different instances of a unitary tort?

In this paper, we argue that there are indeed two different species of inducing breach of contract, only one of which belongs inside Weir's generic tort. The two causes of action have different criteria and, further, have structurally different rationales. Moreover, both causes of action are independently legitimate, in the sense that each of their underlying rationales supplies good reasons why tort law should grant a remedy for D's conduct.

The discussion that follows will proceed in three main parts. First, we explore the possibility that current law implicitly recognises two different types of inducing breach of contract, because it imposes different criteria for the two forms of the action. Second, we consider the justifying rationale behind each of the two forms, by investigating what harm, and what wrong, the torts protect against. Finally, we discuss how the different justifying rationales behind each form of the tort might help to explain some of their doctrinal aspects, including the unfortunate distinction that is sometimes drawn in the cases between "direct" and "indirect" modes of prevention.

\section{Discerning Two Forms of the Tort in the Case Law}

The motivation for thinking that, doctrinally, there are two different species of inducing breach of contract is that they appear to have different legal criteria.

\section{The Range of Plaintiffs}

The locus classicus of inducing breach of contract, Lumley v. Gye, ${ }^{5}$ is an instance of the first paradigm. Its categorising feature is that the inducement is by an act of persuasion. ${ }^{6}$ Although this element has controversial boundaries, ${ }^{7}$ it is not crucial to pursue those

\footnotetext{
5 (1853) 2 E. \& B. 216, 118 E.R. 749. C, a prominent soprano, had agreed with P (an opera impresario) to sing exclusively at Her Majesty's Theatre. D, a rival impresario, was alleged, knowing of C's obligation to $\mathrm{P}$, to have persuaded $\mathrm{C}$ to sing instead at the Royal Italian Opera. On the point of law that arose from P's allegation, the Queen's Bench held that on such facts D would have committed a tort against P. (As it happens, the alleged facts were not later established at trial.) A valuable discussion of the case in its historical context is S.M. Waddams, "Johanna Wagner and the Rival Opera Houses" (2001) 117 L.Q.R. 431. Although a number of the judgments in Lumley v. Gye described C as a "servant", by the end of the nineteenth century it was become clear that the tort extended to protect other forms of contract, ones not for employment or personal services. See Bowen v. Hall (1881) 6 Q.B.D. 333; Temperton v. Russell [1893] 1 Q.B. 715; C. Carpenter, "Interference with Contract Relations" (1928) 41 Harv. L.R. 728.

${ }^{6}$ For convenience, we use the term "persuasion" in the text to cover any mode of persuasive inducement.

${ }^{7}$ In particular, the distinction between persuasion or inducement and advice. We shall say a little more about this distinction infra, at p. 160.
} 
boundaries here: the central point is that, unlike prevention, which is the marque of the second paradigm, persuasion operates through the medium of C's autonomous decision. D does not suppress C's free choices, in the way that a blackmailer or racketeer might. Blackmailers coerce their victims. Through the use of threats, they create a situation in which the victim is obliged to choose an act that he does not welcome, and which otherwise he would not do. The choice that the victim makes is not free; his will is, in a very real sense, subordinated to the will of the blackmailer. When D persuades $\mathrm{C}$ to breach her contract, however, $\mathrm{D}$ does not attack C's right to choose what to do. There is not a threat but an offer; C simply has an additional, and not unwelcome, option which she is free to reject. Hence her choice (if made) to accept D's offer, and in turn to break her contract with $\mathrm{P}$, is $C$ 's choice and not one made subordinate to the will of $\mathrm{D}$.

By contrast, where performance is prevented, $\mathrm{C}$ does not decide to break her promise to $\mathrm{P}$. She is given no choice in the matter. ${ }^{8}$ Thus $\mathrm{C}$ is at least as much a victim of D's interference as is P. Indeed, the wrong to $\mathrm{P}$ is in a sense subsidiary, in that the breach of contract arises as a further consequence of the initial wrongful act committed against C. ${ }^{9}$ In the case of persuasion, on the other hand, the wrong to $\mathrm{P}$ is not a simple consequence of D's intervention: it occurs only when $\mathrm{C}$ subsequently chooses to adopt D's inducement and to break the contract with $P$. This directly affects the requirements of the tort. Where D prevents performance, $\mathrm{C}$ - as well as $\mathrm{P}$ - can sue D for losses arising from the breach of contract. ${ }^{10}$ But where $\mathrm{D}$ induces a breach by persuasion, $\mathrm{C}$ has no right to sue D. ${ }^{11}$ The denial to $\mathrm{C}$ of a cause of action might be thought to be a matter of incentives; ${ }^{12}$ in truth, it is more than that. It recognises that the very "essence" of the persuasion-tort rests in a breach of contract, ${ }^{13}$ and that this wrong is committed by

${ }^{8}$ Or at least an inadequate choice, as when D hinders performance without making it entirely impossible: cf. Dimbleby \& Sons Ltd. v. NUJ [1984] 1 W.L.R. 67 (C.A.), not discussed on this point by the House of Lords [1984] 1 W.L.R. 427.

9 This is why, as we argue below, D's intention to harm P is indispensable to the prevention tort. (Indeed, the immediate wrong may be committed by or against a fourth party, E. This raises the further problem of indirect prevention, discussed below, at pp. 161ff.)

${ }^{10}$ Indeed, C's right of recovery may be even more extensive than P's, since C may sometimes be able to recover foreseeable contractual losses by suing $\mathrm{D}$ for the original unlawful act (as when D, a habitual arsonist, burns down C's factory, foreseeably preventing C from fulfilling her supply contracts with $\mathrm{P}$; something to which D had given no thought).

${ }^{11}$ Boulting v. Association of Cinematograph, Television and Allied Technicians [1963] 2 Q.B. 606, 639-640 (Upjohn L.J.); Williams v. Hursey (1959) 103 C.L.R. 30, 77; Brekkes v. Cattel [1972] 1 Ch. 105, 114 (Pennycuick V.-C.). Cf. Camden Exhibition \& Display Ltd. v. Lynott [1966] 1 Q.B. 555, 569 (Russell L.J.).

12 Cf. Boulting v. Association of Cinematograph, Television and Allied Technicians [1963] 2 Q.B. 606, 639-640: C "must resist [D's] effort by strength of will".

13 Allen v. Flood [1898] A.C. 1, 120-121 (Lord Herschell); cf. Stratford v. Lindley [1965] A.C. 269, 340 (Lord Donovan). 
C. D may also be responsible for the wrong that $\mathrm{P}$ suffers, but D is not the agent of that wrong. It is inflicted by C. Drawing a limited analogy with existing doctrine, to the extent that $\mathrm{C}$ also suffers loss by reason of that wrong, it is self-inflicted and subject to the principle volenti non fit injuria. ${ }^{14} \mathrm{D}$ neither wrongs nor harms C. C harms herself.

\section{Breach and Unlawful Means}

The point that breach of contract is at the heart of Lumley v. Gye underpins the second difference between persuasion and prevention. Doctrinally, it manifests itself in the requirement that D's act of persuasion must result in a breach. Hence, the tort does not lie if C's non-performance is not a breach of contract, e.g., because the contract is $\operatorname{void}^{15}$ or because D procures C legitimately to determine the contract. ${ }^{16}$ Similarly, the tort cannot be committed if a contract has not yet been formed and D merely dissuades $\mathrm{C}$ from entering into one. ${ }^{17}$ As Weir puts it, "it is right that the plaintiff's tort claim lies only if the middleman could be sued for what the defendant got him to do". ${ }^{18}$ The breach of contract is constitutive of the harm to $\mathrm{P}$, and the contractual damages that lie against $\mathrm{C}$ are also the measure of his loss against $\mathrm{D}$.

It is a different matter where $\mathrm{D}$ does not dissuade, but rather prevents, C from performing his obligations. Here, C's failure to perform need not be in breach of contract. One assertion of this rule is found in Torquay Hotel Co. Ltd. v. Cousins. ${ }^{19}$ Esso (C) had contracted to supply the plaintiff hotelier with oil but it then became embroiled in a labour dispute with the defendants who, taking industrial action, instructed Esso's drivers not to make any further deliveries of the oil. $\mathrm{P}$ obtained an injunction against $\mathrm{D}$ on the basis that its right to contractual performance by $\mathrm{C}$ was being interfered with, notwithstanding that a force majeure clause meant that, to adopt Weir's phrasing, C could not be sued when prevented from performing. ${ }^{20}$ According to Lord Denning M.R., "[t]he time has come when the principle [in Lumley v. Gye] should be further

${ }_{14}$ And, indeed, to the principle ex turpi causa non oritur actio.

15 See, e.g., De Francesco v. Burnum (1890) 43 Ch. D. 165, (1890) 45 Ch. D. 430; Joe Lee Ltd. v. Dalmeny [1927] 1 Ch. 300; Greig v. Insole [1978] 3 All E.R. 449.

${ }^{16}$ McManus v. Bowes [1938] 1 K.B. 98, 127 (Slesser L.J.); Cutsforth v. Mansfield Inns [1986] 1 W.L.R. 588, 563, D.C. Thomson \& Co. Ltd. v. Deakin [1952] Ch. 646, 702 (Morris L.J.); Denaby and Cadeby Main Collieries Ltd. v. Yorkshire Miners' Association [1906] A.C. 384, 406; Associated British Ports v. TGWU [1989] 1 W.L.R. 939, 970 (Stuart-Smith L.J.); White v. Riley [1921] 1 Ch. 1, 15, 26, 32.

${ }^{17}$ Midland Cold Storage Ltd. v. Steer [1972] Ch. 630, 644-645; McKernan v. Fraser (1931) 46 C.L.R. 343.

18 Weir, above note 4 , at p. 36 n. 44 .

${ }^{19}$ [1969] 2 Ch. 106 (C.A.).

20 Above, text at note 18 . 
extended to cover 'deliberate and direct interference with the execution of a contract without that causing any breach." ", 21 In order to fall within the extensional case, in his Lordship's view, "there must be interference in the execution of a contract. The interference is not confined to the procurement of a breach of contract. It extends to a case where a third person prevents or hinders one party from performing his contract, even though it be not a breach". 22

Although Lord Denning saw prevention or hindrance as an extensional case, his remarks were not, strictly speaking, necessary, since the appeal in Torquay Hotel could have been decided without needing to make such an extension to existing law. ${ }^{23}$ Be that as it may, other cases have confirmed that $\mathrm{D}$ commits a tort by intentionally preventing $\mathrm{C}$ from performing her contract with $\mathrm{P}$, subject to one important proviso: the means of prevention must be unlawful. ${ }^{24}$ Hence, it is no tort for $\mathrm{X}$ lawfully to buy up the entire market in widgets that, he knows, $\mathrm{Y}$ has contracted to supply to $\mathrm{Z}^{25}$ But it is a tort for $\mathrm{X}$ deliberately to prevent $\mathrm{Y}$ from performing her contract with $\mathrm{Z}$ by stealing all the available widgets-because the theft is itself an unlawful act. ${ }^{26}$ The act of prevention must independently be a tort or otherwise unlawful.

There are scattered dicta that may be read as endorsing a more wide-ranging formulation of the prevention-tort along the lines Lord Denning proposed, most notably in Lord Diplock's judgment in Merkur Island Shipping Corp. v. Laughton. ${ }^{27}$ But such dicta are

${ }^{21}$ Ibid., at p. 138.

22 Ibid. (italics omitted).

${ }^{23}$ The decision may be explicable on two grounds. First, the contract did not exempt $\mathrm{C}$ from the (primary) obligation to supply fuel to the hotel, but rather exempted $\mathrm{C}$ from liability in the event that his failure to perform was prevented by, inter alia, a labour dispute of the sort that occurred. Thus the contract contained "an exception from liability for non-performance rather than an exception from obligation to perform" (per Russell L.J., ibid., at p. 143) and C was, in law, in breach of contract albeit that $\mathrm{P}$ could not sue. Second, the means used by D to prevent $\mathrm{C}$ from performing were in any event unlawful, since they involved procuring $\mathrm{C}$ 's drivers to break their contracts of employment.

${ }^{24}$ Lord Denning accepted a requirement of unlawfulness only where the intervention was indirect: "Indirect interference will not do.... Indirect interference is only unlawful if unlawful means are used". (Ibid., at p. 138; italics in original.) We criticise the distinction between direct and indirect inteference below, at pp. $161 \mathrm{ff}$.

25 Thomson \& Co. Ltd. v. Deakin [1952] Ch. 646, 680 (Evershed M.R.); Torquay Hotel Co. Ltd. v. Cousins [1969] 2 Ch. 106, 138 (Lord Denning M.R.).

${ }^{26}$ Per Evershed M.R. in Thomson \& Co. Ltd. v. Deakin [1952] Ch. 646, 680, "it seems to me that the intervener, assuming in all cases that he knows of the contract and acts with the aim and object of procuring its breach to the damage of $\mathrm{B}$, one of the contracting parties, will be liable ... if he intervenes by the commission of some act wrongful in itself so as to prevent A from in fact performing his contract...". Note that this proposition is subject to qualification, in that the unlawful means used by D must be a wrong against P; it is not enough that D's act is merely unlawful for some incidental reason. See the discussion infra, at p. 146; Lonrho Ltd. v. Shell Petroleum Co. Ltd. (No. 2) [1982] A.C. 173.

${ }^{27}$ [1983] 2 A.C. 570, 608-609 (quoting with approval Lord Denning's statement of the principle reproduced above, text at n. 22). Cf. Law Debenture Trust Corp. v. Ural Caspian Oil Corp. Ltd. [1995] Ch. 152, 167 (Beldam L.J.): "it is an actionable tort knowingly to interfere with 
isolated, flawed, ${ }^{28}$ and outweighed by the weight of authority to the contrary, both in the cases ${ }^{29}$ and in the texts. ${ }^{30}$ In D.C. Thomson \& Co. Ltd. v. Deakin, for example, Lord Evershed M.R. declared that "acts of a third party lawful in themselves do not constitute an actionable interference with contractual rights merely because they bring about a breach of contract, even if they were done with the object and intention of bringing about such a breach". ${ }^{31}$ Moreover, this assertion was no mere dictum but part of the ratio decidendi of the case. By contrast, the few cases where Torquay Hotel has been relied on successfully by the plaintiff, including Merkur Island, are cases where the defendant's act of preventative interference has been independently unlawful. ${ }^{32}$ There appears to be no English case where the plaintiff has succeeded in claiming against a defendant whose otherwise lawful actions prevented performance of contractual obligations. Rightly so. Such a claim could not be reconciled with the fundamental principles laid down in Allen v. Flood, 33 which recognised a legal "chasm" between harm intentionally caused by lawful means and harm caused by means of a legally wrongful act.

It seems clear that, by omitting the requirement for an unlawful act in the prevention-tort, Lord Denning went too far. Yet once the unlawful act is present, it is also clear that liability for prevention

another's right to performance of a contractual obligation by preventing or hindering the other party from performing his obligations under the contract'. But compare, from the same judgment, infra n. 29. See too D.C. Thomson \& Co. Ltd. v. Deakin [1952] Ch. 646, 694-695 (Jenkins L.J.), allowing that there would be liability where D "does an act which, if done by one of the parties to it, would have been a breach". Prima facie, this asserts no requirement for unlawfulness independent of the contract, but Jenkins L.J. continues: "[o]f this type of interference the case of G.W.K. Ld. v. Dunlop Rubber Co. Ld. 42 T.L.R. 376 affords a striking example". That case, the facts of which form the basis of our paradigm Case 2, clearly involved intervention by an unlawful act.

${ }^{28}$ Although Lord Diplock cited the judgment of Jenkins L.J. in D.C. Thomson \& Co. Ltd. v. Deakin [1952] Ch. 646, Jenkins L.J. never contemplated interference falling short of a breach. Moreover, his Lordship relied on the fact that Parliament had, in the then Trade Union and Labour Relations Act 1974, s. 13(1), granted certain immunities from liability for the tort of interference with contract, as evidence that the tort did exist at common law. But that provision was broadly drafted in case of future developments in tort law, not on the basis that such a tort then existed (cf. Rookes v. Barnard [1964] A.C. 1129, 1177 per Lord Reid).

29 E.g., Law Debenture Trust Corp. v. Ural Caspian Oil Corp. Ltd. [1993] 1 W.L.R. 138, 151 (Hoffmann L.J.), where Lord Denning's proposal is regarded as "debatable". The decision was reversed on other grounds ([1995] Ch. 152, C.A.), where Beldam L.J. remarked (at 170) that "I am not persuaded that an act, otherwise lawful but which to the knowledge of the person doing it might prevent a third party from seeking equitable relief against breach of a primary obligation under a contract, is in itself capable of giving rise to a cause of action in tort". Cf. also Middlebrook Mushrooms Ltd. v. TGWU [1993] I.C.R. 612, 620 (Neill L.J.).

30 See, e.g., K.W. Wedderburn, The Worker and the Law (3rd edn., Harmondsworth 1986), 611617; Howarth, above note 3, at p. 484; Weir, above note 4, at pp. 36-39; B. Markesinis and S. Deakin, Tort Law (4th edn., Oxford 1999), 476-477; W.V.H. Rogers (ed.), Winfield and Jolowicz on Tort (15th edn., 1998) 631-632.

31 [1952] Ch. 646, 693.

32 For example, News Group Newspapers v. SOGAT (No. 2) [1987] I.C.R. 181; Falconer v. ASLEF [1986] I.R.L.R. 331; Dimbleby \& Sons Ltd. v. NUJ [1984] 1 W.L.R. 427 (H.L.).

33 [1898] A.C. 1, 121 (Lord Herschell). Cf. The Nadezhda Krupskaya [1997] 2 Lloyd's L.R. 35, 40 (Rix J.); also F.B. Sayre, "Inducing Breach of Contract" (1923) 36 Harv. L.R. 663, 696ff. 
of performance-whether by direct or indirect means ${ }^{34}$ - can lie in tort. Moreover, such liability does not require proof of a breach of contract by $\mathrm{C} .{ }^{35}$

\section{The Mental Element}

Finally, it appears that the mental element required to constitute inducing breach of contract may well differ according to whether the inducement is by persuasion or prevention. Perhaps surprisingly, the difference can be stated neither with confidence nor with exactitude since it is uncertain what is the requisite mental element of inducing breach of contract-in either of its forms. Where D prevents $\mathrm{C}$ from performing, it is likely that $\mathrm{P}$ acquires a cause of action against $\mathrm{D}$ only if $\mathrm{D}$ acts with the intent to harm $\mathrm{P}$, by depriving $\mathrm{P}$ of $\mathrm{C}$ 's performance. ${ }^{36}$ By contrast, it seems that an intent to harm $\mathrm{P}$ is not required when $\mathrm{D}$ persuades $\mathrm{C}$ to breach her contract. Indeed, it may even be that recklessness will suffice. ${ }^{37} \mathrm{We}$ will return to discussion of the metal element below. ${ }^{38}$

\section{Summary}

To summarise: The main structural differences between inducing breach of contract by persuasion and by prevention are fourfold. First, prevention requires a wrong committed by $\mathrm{D}$ independent of any contractual wrong by $\mathrm{C}$. Second, prevention does not require that C's failure to perform be a contractual wrong by C. Third, C (as well as P) can sue D for losses arising from C's nonperformance of the contract only when $\mathrm{D}$ induces that nonperformance through prevention rather than through persuasion. Fourth and tentatively, the mental elements for the two varieties seemingly differ on the need for an intention to harm P.

Do these structural differences disclose that they are, in substance, different torts (or, at least, fundamentally different paradigms of inducing breach of contract)? Given that the third difference can be explained by standard doctrine (volenti non fit injuria), why not, as Weir suggests, simply regard the act of prevention and the persuaded breach of contract as alternative

${ }^{34}$ A distinction to which we return, below, at p. 161.

${ }^{35}$ Merkur Island, News Group Newspapers v. SOGAT [1987] I.C.R. 181; Falconer v. ASLEF [1986] I.R.L.R. 331 (but see n. 97 infra).

36 E.g., D.C. Thomson \& Co. Ltd. v. Deakin [1952] Ch. 646, 697 (Jenkins L.J.); Torquay Hotel Co. Ltd. v. Cousins [1969] 2 Ch. 106, 138 (Lord Denning M.R.). By "acts with the intent to harm P", we mean that D must be acting deliberately in order to harm $\mathrm{P}$ (either for its own sake or in order to achieve some further purpose of D's); the injury to P, even if foreseen, must be more than a mere side-effect of D's actions - it must be something that D has sought to bring about. See further infra, n. 89 and text thereat.

${ }^{37}$ See, e.g., Emerald Construction v. Lowthian [1966] 1 W.L.R. 691, 700-701 (Lord Denning M.R.); but see infra, n. 92 .

38 Below, at pp. 154ff. 
instances of a more general unitary requirement for an unlawful act? Nothing in the analysis so far precludes the logical possibility of that conclusion. As the Legal Realists pointed out decades ago, cases can very often be assimilated under a common principle if one is willing to abstract that principle to a sufficient level of generality. On the other hand, neither does our analysis mandate Weir's proposal. On the contrary, it shows that there is conceptual space in the cases within which two separate torts might be distinguished on non-arbitrary grounds. In the pages below, we argue that there are indeed normatively salient differences, which would be suppressed by Weir's generalisation.

\section{Finding Normative Rationales Behind Liability for Inducing Breach of Contract: Harms and Wrongs}

According to Weir, the economic torts are "concerned with matters less grave" than are torts governing harm to a person's body or property. ${ }^{39}$ One may hesitate to concede this, since the economic torts and, indeed, the protection of property rights must be justified ultimately in terms of the interests of persons. Ultimately, the reason why recent corporate accounting scandals, such as that at Enron, are so concerning is not the fraud per se, or even the amount of money involved, but its widespread and real implications for the lives of human beings: employees now without work (at Enron, its auditors, its dependent suppliers, etc.), shareholders, pension fund holders, and so forth. Whichever the tort, the same questions must always be asked about its legitimacy: how is this tort justified by reference to the interests of persons? What rationale underpins P's claim to state intervention on his behalf and to the detriment of $\mathrm{D}$ ?

A successful account of inducing breach of contract must answer these questions by finding a rationale that both explains the legal doctrine and justifies it. Moreover, if we are right to distinguish between persuasion and prevention, there ought to be two such rationales - one for each form of action. The rationales must, of course, help to explain the doctrinal differences we have observed above. But they must also meet key normative criteria if they are to justify the tort actions that they underpin.

For one thing, the rationale must show why D's conduct is the concern of the state. Frequently situations arise where D ought (or ought not), morally speaking, to act in some particular way. But it does not follow that the state should require that he do so. Tort law is an intrusive and expensive method of restricting the rights of

\footnotetext{
${ }^{39}$ Above note 4, at p. 2.
} 
a society's citizens. At least in a liberal society, this sort of coercive intervention by the state should not be predicated merely on the fact that D's act is a moral wrong: like any field of law, tort law is justified by the fact that it protects the interests of persons, by addressing conduct that has a significant harmful effect on their lives. ${ }^{40}$ This restriction on the scope of tort law plays an important role in moderating the conflicting interests of individual members of a society. It leaves me free to wave my arm around, even if others disapprove. But my freedom runs out at the end of your nose.

Additionally, the rationale must show why the defendant in particular should compensate the plaintiff. Tort law reallocates losses; thus any plausible rationale for inducing breach of contract needs to explain why losses should not lie where they fall-why D should be held liable for the loss that $\mathrm{P}$ suffers. The literature on this aspect of tort theory is considerable, and a full exploration of the issues involved lies outside the scope of the present paper. Broadly speaking, however, we may say that tort law regulates losses that are caused wrongfully. D is liable for P's loss becauseand only when - that loss is attributable to a wrong for which D is responsible. ${ }^{41}$ For liberal theorists, moreover, it is insufficient to show that D's conduct is wrong simpliciter: it must be a wrong to P. Suppose, for example, that $\mathrm{D}$ borrows an old shirt from $\mathrm{P}$ but never returns it. The shirt is worthless and of no use to P; in fact, $\mathrm{P}$ normally throws out his old clothing and he eventually forgets about the existence of the shirt. ${ }^{42}$ Its conversion affects him not at all. Further, the shirt ends up in the hands of $\mathrm{T}$, who is destitute and in great need of clothing. T's welfare interest in the clothes is far greater than P's. Yet $\mathrm{P}$ is wronged by $\mathrm{D}$; and $\mathrm{P}$ wrongs no-one if, later, he discovers the loss and rather selfishly reclaims his shirt from T. P's act of reclamation falls outside the scope of tort law because, although T's welfare is damaged when he is deprived of possession of the clothes, he has lost nothing to which he had a right. $^{43}$

${ }^{40}$ Cf. J.S. Mill's stricture for state action in On Liberty (1859) ch. 1: "the only purpose for which power can be rightfully exercised over any member of a civilized community, against his will, is to prevent harm to others".

${ }^{41}$ This claim holds most straightforwardly for those torts, including inducing breach of contract, where an injunction is available against D's activity. In other torts, it may be that $\mathrm{P}$ is wronged, and D is responsible for that wrong, but D's activity is not ex ante wrongful. The explanation of these torts is more complex: liability may, for example, mandate that D assumes the risk his conduct creates (cf. Rylands v. Fletcher (1868) L.R. 3 H.L. 330). We cannot explore these varieties of torts here.

42 Related examples are discussed by J. Gardner and S.C. Shute, "The Wrongness of Rape" in J. Horder (ed.), Oxford Essays in Jurisprudence (4th series, Oxford 2000), 193, 201 and A.P. Simester and A. von Hirsch, "Rethinking the Offense Principle" (2002) 8 Legal Theory 269, 282.

${ }^{43}$ At least, no right maintainable against P. T may still have possessory rights against someone else. 
For supporters of inducing breach of contract, the challenge is to show how the rationale behind the tort complies with these requirements. In looking to explain and justify any tort of inducing breach of contract, the explanation must therefore identify the generic harm addressed by the tort and show that the harm is sufficiently important to outweigh countervailing considerations, such as institutional transaction costs and values like individual liberty, which militate against any state intervention that places duties on D and restricts his freedom of action. Further, any successful explanation of inducing breach of contract must also show how it is that $\mathrm{P}$ has been wronged, and in what way $\mathrm{D}$ is responsible for that wrong.

In the following sections, we will investigate how the two categories of inducing breach of contract, persuasion and prevention, satisfy these criteria. We will argue that, although both categories of the tort protect against the same generic harm, they differ with regard to the wrong.

Because they involve different wrongs, it follows that these are separate paradigms of inducing breach of contract, which in law generate structurally different causes of action. In order to see this, it may be helpful to make explicit a preliminary analytical point upon which we will place reliance. At the level of doctrine, the form, remedy, and criteria of a tort action should track and respond to the justifying rationale of that action. Cases that are paradigm according to that justifying rationale should satisfy the criteria of the doctrinal action straightforwardly; conversely, cases that are borderline according to that justifying rationale should not, ordinarily, fall squarely within the boundaries of the doctrinal criteria but should lie nearer the periphery and, doctrinally speaking, look more like hard cases. Correspondingly if, as we argue, there are two distinct paradigm causes of action in inducing breach of contract, there should be distinct accounts of how and why each of those torts is legitimate. The distinction, we argue below, lies in the wrong.

\section{The Harm of Inducing Breach of Contract}

Inducing breach of contract protects contractual rights. The instrumental reasons for safeguarding contracts against strangers therefore depend, in turn, upon the grounds for protecting contracts more generally; upon why we should give contractual remedies at all. Identifying those more general reasons has proved controversial, notwithstanding the attentions of a considerable 
literature. ${ }^{44}$ Joseph Raz illustrates the difficulty of this task when he observes: ${ }^{45}$

It follows from the harm principle that enforcing voluntary obligations is not itself a proper goal for contract law. To enforce voluntary obligations is to enforce morality through the legal imposition of duties on individuals. In this respect it does not differ from the legal proscription of pornography.

That is to say, since contractual promises are voluntarily offered and cannot be imposed by another, ${ }^{46}$ making such undertakings obligatory involves the law in enforcing self-created moral duties to benefit another person-analogous to enforcing altruism. This, it may be argued, is an improper function for the State to perform, because it involves the imposition of obligations that, prior to the law's intervention, reside purely in morality (specifically, in the moral value of promise-keeping). Breach of promise may be a moral wrong, but where is the harm?

The answer to that last question may seem, at first glance, straightforward. People tend to rely on the reciprocal promises that constitute a contract. If one of those promises is unfulfilled, anyone who has changed position in anticipation of the promise is likely to suffer loss. On this account, harm appears to be in play and state intervention may, in principle at least, be justified.

Answers of this sort locate the harmfulness of promise-breaking in the reliance by others upon the expectations that a promise generates. They generate a justification of contract law that is framed in terms of one's duty not to let others down when they rely upon one's promise, rather than a duty to keep one's promise per se. Thus they lead toward a reliance-based theory of contract law and not a promissory theory, assimilating the theory of contract with that of promissory estoppel. ${ }^{47}$

Unfortunately, that account of the harm involved in contract will not do. The justifying rationale that it generates cannot explain the law's doctrinal structure, because the central requirements of contract liability do not reflect a reliance-based rationale. In order to establish a cause of action in contract, it is neither necessary nor sufficient for $\mathrm{P}$ to show any change of position consequent upon D's promise. What $\mathrm{P}$ must show is offer and acceptance: an

${ }^{44}$ A useful survey can be found in Stephen A. Smith, "Towards a Theory of Contract" in J. Horder (ed.), Oxford Essays in Jurisprudence (Fourth Series, Oxford 2000), 107.

45 J. Raz, "Promises in Morality and Law" (1982) 95 Harv. L.R. 916, 937. The objection is explored more fully by Smith, supra n. 44, at pp. $109 \mathrm{ff}$.

46 Cf. such well-known cases as Felthouse v. Bindley (1862) 11 C.B. (N.S.) 859, 142 E.R. 1037.

${ }^{47}$ See, e.g., the work of Patrick Atiyah, The Rise and Fall of Freedom of Contract (Oxford 1979); Promises, Morals and Law (Oxford 1981); "Contract, Promises and the Law of Obligations" in his Essays on Contract (Oxford 1986) 10. 
agreement, not reliance upon that agreement. Further, even though $\mathrm{P}$ frequently suffers loss when $\mathrm{D}$ breaches a contractual undertaking upon which $\mathrm{P}$ has relied, reliance losses are not the measure of contractual damages. Contractual remedies are not calculated by reference to compensation for loss suffered, but by reference to making good P's legitimate contractual expectations. Thus, although reliance theories might be capable of justifying some, hypothetical, system of private law, they do not justify the common law of contract that we have because they cannot explain the core features of that system. Another rationale must be found.

A more promising attempt to justify the institution of contract involves likening contracts to property. On this view, the promises we receive form part of our stock of goods; they are part of our personal resources with which we may improve our own lives. In turn, we are harmed when those promises are broken because our stock of goods is diminished. Hence the rules governing formation of contract are, at root, like the rules governing the creation of legal interests in property. ${ }^{48}$

One strength of this analogy is that it transfers easily to the tort of inducing breach of contract, since it disposes of the conceptual objection that inducing breach of contract effectively allows contracting parties by their acts to impose legal duties upon strangers. Acts that lead to the creation of property rights do just the same thing; hence the objection fails, at least qua conceptual objection. $^{49}$

The property metaphor suggests that the rationales underpinning the State's enforcement of property rights might analogously be deployed to justify the State's enforcement of contract rights. This seems right, but we must still be careful about the analysis. It will not suffice to point to the violation of the (property or contract) right per se as supplying the wrongful harm that warrants state intervention. That would lead to a circularity because, in most modern societies, property and contract rights are not pre-legal. Rather, their recognition (and redistribution) is itself a matter of legal rules, and moreover of rules that have varied considerably across different periods of social and common-law development. It

${ }^{48}$ For an argument along these lines, see Smith, above note 44. In Smith's account, promises are constitutive of a special relationship between promisor and promisee. Hence his account can be aligned with the one here, in that the special relationship, which is intrinsically valuable, can be regarded as a part of the promisor's stock of goods. Even so, given that these are voluntarily created goods, it is not obvious how Smith's move is enough by itself to satisfy the requirement for harm (as he thinks it does), without the further arguments made here.

${ }^{49}$ It remains, of course, a prima facie reason against having such a tort, since it involves a circumvention of those strangers' freedoms, a circumvention to which they have not assented. The harm at stake in inducing breach of contract must therefore be sufficient to outweigh the harm inflicted by restricting those freedoms. 
follows that the harm resulting from a violation of such rights cannot, by itself, justify legal remedies since the very existence of those rights is determined by the state-and their legitimate protection by tort would, in effect, be self-justifying and without an independent moral basis.

Rather, state enforcement of contractual promises is warranted because the community as a whole would also suffer harm were the general regime of contract law to be undermined. The relevant harm is thus of a lost-opportunity kind, where the ineffectiveness of a contract-law regime would result in a substantial loss of opportunity for personal and social advancement through reliable coordinated economic activity. Minimising or preventing that prospective, lost-opportunity, harm underpins state intervention to enforce contracts. ${ }^{50}$

The force of this justification depends on the crystallizing role of rights. To recall the example given earlier, misappropriating P's old clothes harms not only the interest, if any, that $\mathrm{P}$ has in the clothes; it also undermines the regime by which P's property right in the clothes is recognized. That is to say, more than one type of interest is at stake when P's clothes are converted. Apart from P's immediate interest in the clothes, both $\mathrm{P}$ and others have an interest in the existence of a system for allocating and reallocating property rights in general. Thus, even where a conversion does not set back P's personal interests, it sets back the interest we all have in the effective existence of a property law regime. The regime itself serves our well-being, by providing a reliable means through which we can seek to improve our own lives via the voluntary acquisition, use, and exchange of resources. Having such a regime augments our autonomy: it does so even if the particular form of the regime is distributively imperfect and fails in itself to secure an optimal set of proprietary entitlements for citizens. ${ }^{51}$ The same can be said for breach of contract, where the harm lies not only in a loss of expectation to $\mathrm{P}$ under the contract (a loss that may or may not damage P) but, more fundamentally, in the consequent undermining of the practice of exchanging enforceable promises. Even if this practice is flawed, its reliability promotes our well-being.

\footnotetext{
${ }^{50}$ See also J. Danforth, “Tortious Interference with Contract: A Reassertion of Society's Interest in Commercial Stability and Contractual Integrity" (1981) 81 Col. L.R. 1491, $1511 \mathrm{ff}$. This is not to deny that non-fulfilment of a contractual promise may harm $\mathrm{P}$, or that inducing breach of contract should protect against this harm; but the harm is parasitic. It provides a justification for intervention only once it is accepted that the institution of contract should be defended by the state. Once the case for a regime of contractual rights is accepted, further more specific harms may be crystallised by the rights themselves. The reservation here is that those more specific harms do not justify state intervention unless the regime by which they are created is itself justified.

${ }^{51}$ See J. Coleman, Risks and Wrongs (Cambridge 1992), 350-354.
} 
By extending liability to strangers who induce breaches of contract, tort law protects $\mathrm{P}$ from any particular loss he may suffer when $\mathrm{C}$ does not perform as promised, and protects the regime of contract law generally. Assuming that it does in fact play a role in deterring some instances of contractual breaches, ${ }^{52}$ the tort therefore satisfies the requirement for harm. Moreover, the harm against which it protects is the same, irrespective whether the tort is committed by persuasion to breach or by prevention of performance. In both forms of the tort, D's actions attack P's right to performance and, behind that, the practice of exchanging promises to create enforceable agreements. ${ }^{53}$ They do so by undermining the dependability of the promise that $\mathrm{P}$ receives; which in turn restricts P's ability to plan his life, both in reliance on the promises he has exchanged already and in reliance on the expectation of being able to improve his life by entering into transactions in the future.

\section{The Wrongfulness of Inducing Breach of Contract}

We conclude that the prevention of harm does supply a ground why the state should intervene to remedy inducing breach of contract, and that the ground it supplies is indifferent between persuasion and prevention. However, as we noted earlier, harm is not by itself sufficient to justify intervention, since there must also be a reason why $\mathrm{D}$, in particular, should bear the cost of P's lossthere must be a reason why $\mathrm{D}$ wrongs $\mathrm{P}$. The next task is to identify that reason.

\section{A generic wrong?}

For Weir, the wrong is generic: the wrongful act is one that causes harm (i) where the harm is intentional and (ii) the act involves an unlawful means. ${ }^{54}$ As such, Weir argues that the entirety of inducing breach of contract has been absorbed within, and should be understood as an instance of, the more general tort of intentionally

52 While this assumption seems to us to be reasonable, in principle it raises an empirical question that we cannot investigate here.

${ }_{53}$ This practice is undermined even in the case of efficient breach; in our view, inducing breach of contract cuts across the distinction between efficient and inefficient breach. Thus the problem of efficient breach is no more a challenge to inducing breach of contract than it is to contract law itself - the former challenge is parasitic on the latter. Indeed, efficient breaches do not imply third parties at all, let alone third parties who initiate breaches. In any event, as we argue below, damages for persuasion to breach are measured by contractual damages; hence, the operation of any efficient breach doctrine would, as it should, feed indirectly to the tort by means of the contract.

54 Weir, "Chaos or Cosmos? Rookes, Stratford and the Economic Torts" [1964] C.L.J. 225, 226: it is "tortious intentionally to damage another by means of an act which the actor was not at liberty to commit". Cf. Weir, above note 4 , at p. 28 . 
causing harm by unlawful means. On that analysis, prevention and persuasion are assimilated.

It is a great strength of Weir's analysis that he identifies intentionality as part of what makes D's conduct a wrong. For the moment, however, we shall defer this difficult point and focus on the element of unlawfulness. That element is, we think, problematic. At the generic level, the meaning of "unlawful means" may seem clear, but it is not. Indeed, it is insufficient that the act is unlawful. ${ }^{55}$ What is required is that D's act be a wrong against $P$; the bare fact that an act is unlawful, even criminal, may not establish that requirement, since the illegality may arise for an entirely unrelated reason. ${ }^{56}$

In respect of preventing performance, this problem of vagueness about what counts as unlawful cannot be avoided. In the famous case of Allen v. Flood, ${ }^{57}$ the House of Lords decided conclusively that it is no tort for D intentionally to inflict economic harm. ${ }^{58}$ The true general tort, on their Lordships' analysis, ${ }^{59}$ arises only where D intentionally causes harm to $\mathrm{P}$ using wrongful means. Hence, where $\mathrm{D}$ prevents $\mathrm{C}$ from performing, his intention to harm $\mathrm{P}$ is insufficient; we must also enquire whether that preventative act was independently unlawful.

By contrast, when the breach is induced by persuasion, in Weir's analysis the unlawful means requirement can be met by one event only: the breach of contract itself. Correspondingly, we saw earlier that no action lies where the contract is void or C's response is a valid rescission. ${ }^{60}$ Contractual breach may seem a more straightforwardly identifiable event, but there are two difficulties about using the fact of breach to crystallise liability. First, what of the case where $\mathrm{D}$ causes $\mathrm{C}$ to breach her contract by using lawful means to prevent performance? That, as we have noted, is not a tort, ${ }^{61}$ but if breaching the contract is itself an unlawful means,

\footnotetext{
55 "It is, however, not every 'unlawful' act or means which allows for an action in tort, even if damage is intended and caused". Clerk and Lindsell on Torts (18th edn., 2000) § 24-91. For example, it appears that contempt of court does not count as unlawful means: Chapman v. Honig [1963] 2 Q.B. 502, approved in Harrow LBC v. Johnston [1997] 1 W.L.R. 459, 471 (Lord Hoffman); contrast Acrow (Automation) Ltd. v. Rex Chainbelt Inc. [1971] 3 All E.R. 1175. See H. Carty, "Intentional Violation of Economic Interests: The Limits of Common Law Liability" (1988) 104 L.Q.R. 250, $265 f f$.

56 Cf. Lonrho Ltd. v. Shell Petroleum Co. Ltd. (No. 2) [1982] A.C. 173.

57 [1898] A.C. 1.

58 Notwithstanding that it is a tort intentionally to inflict physical harm to the plaintiff, cf. Wilkinson v. Downton [1897] 2 Q.B. 57, 58-59. The division extends to negligence: "The infliction of physical injury to the person or property of another universally requires to be justified. The causing of economic loss does not". Murphy v. Brentwood DC [1991] 1 A.C. 398, 487 (Lord Oliver).

59 As Weir argues, above note 4 , at pp. $21 \mathrm{ff}$.

${ }^{60}$ See above, text at note 15 .

${ }^{61}$ Above, text at and following note 24 .
} 
then prima facie it satisfies Weir's criteria in this case too. Weir resists that conclusion: ${ }^{62}$

The case is entirely different where I disable the contractor from performing though he would if he could, or it otherwise what I do has the immediate effect, without any intervening conduct or decision on the part of anyone else, that $\mathrm{P}$ does not get what was promised.... Just as I am not liable for persuading the contractor to do something which involves no breach, so I am not liable for preventing his performance, whether that causes a breach or not. I shall of course be liable if I myself use wrongful means in either case, but not if I don't.

So: on Weir's account, the breach of contract is, vis-à-vis $\mathrm{D}$, an unlawful means when it is freely chosen by $\mathrm{C}$ with $\mathrm{D}$ 's encouragement; but not when it is caused, without C's consent, by D's actions. This analysis is unconvincing. The exception Weir seeks to carve out is ad hoc. In both cases, C's failure to perform is a breach of contract and if, in virtue of being a breach of contract, it is unlawful in one case then it must be unlawful in the other. The classification of specific torts within a generic category of this sort is only meaningful if the unifying element, unlawfulness, has some independent content that does not vary across those specific torts. In Weir's analysis, clearly, that is not the case. ${ }^{63}$

There is another problem about relying on the breach of contract to crystallise liability. It is true that only in the case of persuasion does $\mathrm{C}$ make a deliberate choice to breach. Unquestionably, that deliberate breach wrongs $\mathrm{P}$, by violating P's right to performance. But if anything, it seems even harder to regard that breach as a means by which $D$ harms $\mathrm{P}$ than it does in the case of prevention. When chosen deliberately, the breach is not D's act. It is C's. C's wrong, moreover, is fully remedied by the law of contract. This being the case, why make $\mathrm{D}$ responsible for that breach? ${ }^{64}$ Weir's account lacks the resources to tell us when, and why, D's conduct can be married with C's wrong so that D is implicated in that wronging of P. We need further reasons, besides pointing to the breach of contract, why $\mathrm{D}$ should be held responsible for the harm that $\mathrm{P}$ suffers.

${ }^{62}$ Above note 4 , at p. 35 .

${ }^{63}$ Neither, it seems, is this true of tort law more generally. See, e.g., Rookes v. Barnard [1964] A.C. 1129, 1209-1210 (Lord Devlin), Associated British Ports v. TGWU [1989] 1 W.L.R. 939 (C.A.; reversed on other grounds, ibid., H.L.), and Barretts and Baird (Wholesale) Ltd. v. IPCS [1987] I.R.L.R. 3, 9, where it is suggested that what constitutes an unlawful means may differ across different economic torts.

${ }^{64}$ As Howarth puts it (above note 3, at p. 484), "there is no reason to give the plaintiff remedies beyond its contractual remedies ...". 


\section{Grounding the wrong in the harm}

One way of approaching this challenge is to consider whether $\mathrm{P}$ is wronged in any other way - in particular, whether $\mathrm{P}$ has any other rights that are violated apart from his right to C's performance. In an important recent essay, Roderick Bagshaw proposes that $\mathrm{P}$ has two prima facie entitlements, constituting the "protectable interest" behind actions for inducing breach of contract. The entitlements are, first, to C's willingness to perform (the persuasion-right) and, second, to C's existing capacity to perform (the prevention-right). ${ }^{65}$ In Bagshaw's analysis, these are rights somewhat akin in nature to property rights, ${ }^{66}$ in that they are not held against a particular person but can be asserted against the rest of the world; albeit their protection through tort law is less comprehensive than is the protection generally afforded to property per se.

There are a number of implications of this type of approach. By formulating the protectable interests as property-like entitlements, Bagshaw redirects attention from the wrong to the harm. Each entitlement, when attacked, represents a form of harm. At the same time, since both those forms of harm are similarly proprietary-like, Bagshaw suggests that procuring a breach and preventing performance might be assimilated as a unitary tort. ${ }^{67}$ The analogy with the property torts also makes it plausible that the requirements of liability for the tort might include a less stringent mental state than direct intention by $\mathrm{D}$ to induce a breach. Given that it is prima facie wrong to infringe another person's proprietary entitlement, the function of mental state requirements in property torts seems mainly to be establishing sufficient fault for liability to rest with D. Recklessness, or even negligence, might suffice for that task.

Notwithstanding the obvious attractions of Bagshaw's analogy, it seems to us that these formulations of P's entitlement are inappropriate. Moreover, they are inappropriate for very different reasons, something that points against rather than toward their assimilation. Consider, first, the possibility that $\mathrm{P}$ has an entitlement-right to C's existing capacity to perform. The metaphor is overtly proprietary: we might say that, by preventing performance, D "misappropriates" C's capacity to perform. But even if we grant such a metaphor, the misappropriation is from $\mathrm{C}$.

\footnotetext{
65 "Inducing Breach of Contract" in J. Horder (ed.), Oxford Essays in Jurisprudence (Fourth Series, Oxford 2000), 131, 137.

${ }^{66}$ An account that is not without precedent: see, e.g., F. Pollock, The Law of Torts (London 1887) 451; W. Anson, Principles of the English Law of Contract (10th edn., Oxford 1903) 242. See also R. Epstein, "Inducement of Breach of Contract as a Problem of Ostensible Ownership" (1987) 16 J. Leg. Stud. 1.

${ }^{67}$ Above note 65, at pp. 146-148.
} 
It is not obvious why it is a taking from $\mathrm{P}$. Why would $\mathrm{P}$ have a corresponding right of that sort? The core of the contract is that $\mathrm{P}$ has bargained for, or bought a right to, C's performance, typically at some future date. However difficult or easy it becomes for $\mathrm{C}$ to perform-and for whatever reason- $\mathrm{P}$ has no cause of action against anyone unless $\mathrm{C}$ does not, in fact, perform. Indeed, at the time the bargain is made, $\mathrm{C}$ may have no existing capacity to perform. Neither does that by itself matter, provided $\mathrm{C}$ acquires that capacity in time to complete. Thus what seems to matter is not C's existing capacity but her future capacity to perform. Yet on that count, it seems clear that $\mathrm{P}$ can have no right held against the rest of the world to C's future capacity to perform, since that would impose positive duties upon strangers to ensure that $\mathrm{C}$ acquires such a capacity. ${ }^{68}$ If $\mathrm{P}$ has any right of this sort, it can only be an action-right: a right that strangers not act to prevent $\mathrm{C}$ from performing. To conceive of the tort as protecting an interest in C's existing capacity to perform generates an unstable analysis.

It is also inapt to conceive of $\mathrm{P}$ as having a quasi-property right, held against the rest of the world, to C's willingness to perform. For one thing, analogies to property rights are inadmissible in the context of another person's mental state. Hence the metaphor of theft does not carry over into persuasion-D cannot be said to "steal" C's willingness to perform. Crudely put, people are not objects. When it comes to other persons' attitudes, emotions, intentions, and the like, ownership analogies are entirely misplaced; indeed, they are inconsistent with the principles of individual autonomy that are cornerstones of any liberal society. It is true that moral rights of this sort exist: my son has a right that I think of him as a human being, and not just as a thing to be treated well and programmed into adulthood. But such rights are not the stuff of law. Legal rights are properly concerned with how people behave, rather than with who they are or what they think.

More generally, there is a fundamental problem about explaining the wrongfulness of inducing breach of contract using property-based analogies. The unarticulated premise underlying this approach is that causes of action can only be differentiated if they remedy different harms (or, in Bagshaw's analysis, if they protect different interests). According to this view, if the harm is the same then the wrong must be the same, since the wrong consists simply in the unjustified causing of that harm. But the relation between

${ }^{68}$ A point seen by Bagshaw: ibid., at pp. 137-138. Indeed, a similar objection might be made to the claim that $\mathrm{P}$ has a right to C's existing capacity to perform. Prima facie, such a right could generate a positive obligation of maintenance in strangers, e.g., to repair diminutions in C's capacity to perform. 
harm and wrong is not this simple. Many actions are defined not exclusively in terms of their effects, harmful or otherwise, but also in terms of the intentions with which they are done. John Finnis conveys this point nicely when he describes ${ }^{69}$

... the common unsound assumption that human acts can be identified, for the purposes of moral or legal assessment, independently of the acting person's intention(s). But countless acts cannot be truly identified for what they are (prior to assessment as right or wrong, lawful or unlawful) unless and until the outward behaviour which they involve is understood as the carrying out of such and such an intention. Should this pat on the back be deemed a greeting, a warning, an encouragement, a condescension, a code sign to waiting police officers, or something else?

In Finnis's example, the actor's intention is integral to the nature of the action he performs. It is also integral to the moral character of that action. ${ }^{70}$ Thus it may be only the actor's intention which makes an action wrong. For this very reason, blackmail cannot be committed inadvertently. ${ }^{71}$ Neither can duress more generally. If we focus simply on the harmfulness of actions, there is a tendency to ground the wrong just in the harm and to treat the differences between D's mental states simply as a matter of relative degrees of fault. That is an error. Sometimes the difference between D's intentionally bringing about an outcome and his doing so negligently resides not just in the degree of culpability, but also in a changed wrong ${ }^{72}$ or even a wrong where there is none otherwise. ${ }^{73}$ Hence a person who sets out to inflict economic injury on $\mathrm{P}$ wrongs $\mathrm{P}$ in a way that is fundamentally different from another person who inadvertently but carelessly does something that leads $\mathrm{P}$ to suffer economic loss. ${ }^{74}$ That difference cannot be captured by describing the harm, or "protectable interest", at stake. The harm is the same.

69 "Intention in Tort Law" in D.G. Owen (ed.), Philosophical Foundations of Tort Law (Oxford 1995) 229, 239.

${ }^{70}$ It is no accident that one of the film versions of Choderlos de Laclos's book, Les Liaisons Dangereuses, is entitled Cruel Intentions.

${ }^{71}$ Cf. G. Lamond, "Coercion, Threats, and the Puzzle of Blackmail" in A.P. Simester and A.T.H. Smith (eds.), Harm and Culpability (Oxford 1996) 215. Lamond points out that a key difference between a blackmailing threat and an offer or a warning lies in the intentions of the person who delivers it.

72 For example, the distinction between vandalism and negligent property damage is not simply that the former is more culpable. Vandalism expresses a contempt for society and for the victim that negligently causing damage does not.

73 Thus advice that warns a person of the consequences is not persuasion: Cutsforth v. Mansfield Inns Ltd. [1986] 1 W.L.R. 558, 563 (Sir Neil Lawson). Neither is it a threat or intimidation: White v. Riley [1921] 1 Ch. 1, 13 (Lord Sterndale M.R.).

${ }^{74}$ Finnis, supra n. 69. Finnis's depiction (at p. 241) of "the Allen v. Flood rule that motive or intention is irrelevant" is something of a misdescription. Intention is relevant, and not just in the case of conspiracies. Allen v. Flood only decides that it is insufficient. 


\section{The practice of promising}

We conclude that neither Weir's nor Bagshaw's accounts are capable of explaining fully what is wrong about inducing breach of contract. The underlying reason for this, we think, is that both accounts disregard an important, contract-related, wrong that is involved in persuading $\mathrm{C}$ to breach. This wrong reflects a second moral right that $\mathrm{P}$ acquires when she enters into a contract with $\mathrm{C}$, over and above the obvious moral and legal right to performance. Assuming, as we do, that the foundation of contract is agreement by means of promises, let us consider the nature of promising. As Raz puts it, the principles that best explain the activity of promising: ${ }^{.5}$

present promises as creating a relation between the promisor and promisee-which is taken out of the general competition of conflicting reasons. It creates a special bond, binding the promisor to be, in the matter of the promise, partial to the promisee. It obliges the promisor to regard the claim of the promisee as not just one of the many claims that every person has for his respect and help but as having peremptory force.

A promise changes the relationship between promisor and promisee: the promise, once given, creates a reason that did not previously exist, obliging the promisor to treat the promisee as special. We can illustrate this point with an example. Suppose Jane promises to give $£ 100$ to charity $X$ at the end of the month, because she wishes to support its famine-relief activities in Africa. Before the end of the month arrives, Jane discovers that charity $\mathrm{Y}$ is spending a higher proportion of its received donations upon famine relief in Africa. Her original reasons for giving the money would, she now sees, be better served by giving the money to Y. But, by promising to give the money to $\mathrm{X}$, Jane has introduced a new factor: a pre-emptive reason, to do as she promised and not to reconsider.

It follows from the nature of promising that the promisee has two rights: the right to pre-emptive status in the promisor's reasoning, and the right to performance. When $\mathrm{C}$ promises $\mathrm{P}$ that she will do $\mathrm{X}$, she obliges herself to do $\mathrm{X}$, and she also obliges herself to do $\mathrm{X}$ because she promised to (and not because, when the time came, she reconsidered and made a fresh decision to do X). In so doing, and by marking out $\mathrm{P}$ as special - as the beneficiary of peremptory reasons $-\mathrm{C}$ creates a special relation between herself and $\mathrm{P}$, a relation that is intrinsically valuable. ${ }^{76}$ Wrongdoing by $\mathrm{C}$

75 J. Raz, "Promises and Obligations", in P.M.S. Hacker and J. Raz (eds.), Law, Morality and Society (Oxford 1977) 210, 227-228.

${ }^{76}$ Cf. Raz, "Promises in Morality and Law" (1982) 95 Harv. L.R. 916, 928: "The moral presuppositions of this conception of promising are the desirability of special bonds between people and the desirability of special relations that are voluntarily shaped and developed by the choice of participants". 
may vest in either of these facets of promising, and indeed $\mathrm{C}$ may wrong $\mathrm{P}$ even if she does as she promises. Consider the following example:

Uncle $\mathrm{U}$ promises his nephew $\mathrm{N}$ that he will give $\mathrm{N} £ 100$ if $\mathrm{N}$ passes his forthcoming examinations. $\mathrm{N}$ does pass. Upon hearing this news, $\mathrm{U}$ thinks further about whether to give $\mathrm{N}$ the $£ 100$ and decides to do so, reasoning that his giving $\mathrm{N}$ the money on this occasion will reinforce the incentive for $\mathrm{N}$ should $U$ decide to make any similar promises in the future.

Does $\mathrm{U}$ wrong $\mathrm{N}$ ? We think he does, in that although $\mathrm{U}$ ultimately pays up as promised, he does so for the wrong reasons - not simply because he promised. ${ }^{77}$ The moral worth of U's action is tainted by the fact that it done for manipulative purposes, and $\mathrm{N}$ would be entitled to be hurt were he to discover the truth of U's motives. This facet of promising underpins Weir's depiction of the wrong in play when D persuades C not to perform: ${ }^{78}$

If I persuade someone, whether by stick or carrot, to conduct himself at variance with his duties under a contract, I have altered his conduct, I have perverted him, or converted him to my use as a means of inflicting harm which would otherwise not occur....

Weir rightly distinguishes the simple "I have altered his conduct" from the further "I have perverted him". When D persuades C not to perform, D not only undermines the performance of the undertaking, but also successfully attacks the very status of that undertaking as a reason-generating promise. Contrast prevention, where C's conduct is also altered but where, from P's point of view, the only thing attacked is the performance itself. $\mathrm{C}$ is not "seduced" 79 into disregarding her promise.

This explains why, in the case of persuasion, D's actions are intimately bound up with the breach of contract even though that breach is committed freely by $\mathrm{C}$. The breach is not caused by D. It is committed by $\mathrm{C}$, but $\mathrm{D}$ is also responsible for the wrong to $\mathrm{P}$ causation is not the only way of being involved. ${ }^{80}$ In a sense, D becomes answerable to $\mathrm{P}$ not because he directly harms $\mathrm{P}$ but because he attacks the contract itself. D subverts the peremptory nature of C's contractual promise, something to which $\mathrm{P}$ has a

${ }^{77}$ It does not follow, of course, that $\mathrm{N}$ should be able to sue $\mathrm{U}$ for breach of contract. He is wronged, but he suffers no legally-recognised harm.

78 Above note. 4, at p. 34 (italics in original).

79 Ibid., at p. 35.

${ }^{80}$ Cf. P. Sales, "The Tort of Conspiracy and Civil Secondary Liability" [1990] C.L.J. 491, esp. 502ff; D.J. Ibbetson, A Historical Introduction to the Law of Obligations (Oxford 1999), 180 (noting that forms of civil secondary liability appear to have been founded upon analogies to the criminal law). 
beneficial right. Thus the connection between $\mathrm{D}$ and the wrong to $P$ runs through the contract.

At the same time, because the breach is autonomously chosen by $\mathrm{C}$ it is misleading to depict $\mathrm{C}$, as Weir does, as having been "used" by D. The language of use might suggest that D exploits C in order cause harm to $\mathrm{P}$ by means of the breach of contract: that $\mathrm{C}$ is merely D's instrument. But nothing in the persuasion tort requires that there be any exploitation, or that $\mathrm{D}$ wrong $\mathrm{C}$ in any way. The tort is committed even when $\mathrm{C}$ chooses freely to alter her conduct. Neither is there any requirement that $\mathrm{D}$ be aiming at $\mathrm{P}$ in any way: D's concern may simply be to obtain C's performance for himself. It is a seduction, not a use.

Conversely, in the case of prevention, there is nothing distinctively contractual about the harm that $\mathrm{P}$ suffers. What counts is that $\mathrm{P}$ suffers a harm, and that harm was inflicted deliberately by $\mathrm{D}$ using unlawful means. The distinctive feature associated with contractual rights - that $\mathrm{C}$ will act because of his promise-is not attacked. Hence, it is not a contractual wrong that makes D answerable to $\mathrm{P}$ but rather, as we shall see below, D's intention to harm $\mathrm{P}$. As such, the prevention tort seems rightly analysed by Weir and others as a standard category of the more general tort of causing economic loss by unlawful means (or, as doctrine would have it, of unlawful interference with trade).

\section{Some Doctrinal Pay-OFfs}

The rationales that we have identified both account for, and differentiate between, the wrongfulness of persuading $\mathrm{C}$ to breach and of preventing $\mathrm{C}$ from performing. In so doing, they help to explain some of the central features of the two torts. There is not scope here to consider, let alone resolve, all the doctrinal issues surrounding inducing breaches of contract; our remarks on the following pages are necessarily illustrative and selective. But it seems to us that the resolution of many of these issues has been hampered - indeed, made impossible — by a failure in the case-law to distinguish clearly between the two causes of action. The task is greatly facilitated once the requirements of each tort are separately debated.

\section{Breach and Unlawful Means}

First, and perhaps most obviously, it can now be seen why prevention of performance need not be tied closely to remedies for contractual breach. Torquay Hotel turns out, on its facts, to be 
rightly decided ${ }^{81}$ In the prevention tort, it is necessary to show that $\mathrm{D}$ causes harm to $\mathrm{P}$, and this harm may be established by reference to contractual expectations; but there is no reason why the measure of damages should be limited by the contract, since the wrongfulness of causing that harm arises independently of the contract - it rests in the unlawful means used by D and in the fact that those means were used with intention to harm $\mathrm{P}$. The fact that no claim for damages lies against $C$ is, on this analysis, neither here nor there.

By contrast, inducing breach of contract by persuasion is bound tightly to C's breach of an enforceable promise, since it is D's role in undermining the promise that constitutes his wrong to $\mathrm{P}$. Thus it seems right that the tort does not lie against $\mathrm{D}$ where breach of contract does not lie against $\mathrm{C}$, for example because the contract is void or because $\mathrm{D}$ has merely persuaded $\mathrm{C}$ legitimately to determine the contract. ${ }^{82}$

\section{The Mental Elements}

Second, our analysis also has implications for the mental elements required by the two torts; the requirements for which, as we noted earlier, are somewhat unclear. It is generally accepted that negligence is insufficient. ${ }^{83}$ Beyond that, the case law is unresolved.

At first blush, there is considerable authority that an act of inducing a breach of contract must be intentional, and that D must know about the existence of the contract: thus there is said to be a "two-fold" requirement, ${ }^{84}$ for knowledge ${ }^{85}$ of the contract and an intention to induce its breach. ${ }^{86}$

Yet it is doubtful to what extent this really is a "two-fold" requirement. Markesinis and Deakin, for example, assert that "[t]he relevant mental state is that of intention: the defendant must intend

81 Above, text at note 19.

82 Above, text at note 15 .

83 Lubenham Fidelities and Investments Co. Ltd. v. S Pembrokeshire DC (1986) 33 B.L.R. 39, 7376 (C.A.).

84 Merkur Island Shipping Corp. v. Laughton [1983] 2 A.C. 570, 608 (Lord Diplock); Middlebrook Mushrooms Ltd. v. TGWU [1993] I.C.R. 612, 621 (Neill L.J.).

85 Sometimes, knowledge of the contract will be imputed, especially in interlocutory hearings. But this appears to be an evidential rather than a substantive step, not being one that introduces liability for inadvertent acts of inducement: thus "a third party may be deemed to know of the almost certain existence of a contract and indeed of some of its likely terms" (Middlebrook Mushrooms Ltd. v. TGWU [1993] I.C.R. 612, 621 per Neill L.J.), this is really a matter of inference (cf. Stratford v. Lindley [1965] A.C. 269, 324: "reasonable to infer" per Lord Reid) from circumstances where anyone in D's position would have known of the existence of the relevant contracts; typically, where D is an experienced trade union official who is familiar with the workings of his industry (cf. Merkur Island Shipping Corp. v. Laughton [1983] 2 A.C. 570, 608, per Lord Diplock).

86 See, e.g., D.C. Thomson \& Co. Ltd. v. Deakin [1952] 1 Ch. 646, 695 (Jenkins L.J.): "with knowledge of the contract and the intention of bringing about its breach"; Rookes v. Barnard [1964] A.C. 1129, 1212 (Lord Devlin). 
to interfere with the plaintiff's contractual rights, in the sense of doing so knowingly". ${ }^{87}$ But there is no ordinary sense of "intend" that means "knowingly". One can intend an outcome without knowing that it will occur ${ }^{88}$ and, conversely, one who induces a breach of contract knowingly may not intend so to do. Strictly speaking, D intends only those outcomes that he acts in order to bring about. That is to say, D intends a result only if he acts with the aim, purpose, or object of bringing that result about, either for its own sake (i.e., as an end in itself) or for the sake of achieving some further outcome to which the intended result is a means. Things done as means or ends are intended; side-effects, even known side-effects, are not. ${ }^{89}$ The judge who sentences a criminal to jail may know that, in so doing, she will prevent him from performing his employment-contract obligations. Yet no-one would suggest that she thereby intends that outcome.

In other cases, however, D's knowledge appears to be crucial to his liability. Consider, for example, the scenario in Lumley v. Gye. ${ }^{90}$ $\mathrm{D}$ persuaded $\mathrm{C}$ to sing at D's theatre, realising that doing so would put $\mathrm{C}$ in breach of her obligation to sing exclusively for $\mathrm{P}$. Very often, in such circumstances D acts as he does in order to secure $C$ 's singing services; being content to do so whether or not that would put $\mathrm{C}$ in breach of contract with $\mathrm{P}$. D does not seek to bring about the breach of contract by $\mathrm{C}$ either as a means or an end. Rather, he is liable because he knows that breach is an inevitable side-effect of the end that D seeks (C's singing for D).

Given that cases such as this are-rightly-paradigm examples of the tort, this may seem to support the view that, at least in respect of persuasion, the true focus of the law is on the element of knowledge, or perhaps even recklessness, rather than on intention. Lord Denning M.R. thought so in Emerald Construction Co. Ltd. v. Lowthian, asserting "it is unlawful for a third person to procure a breach of contract knowingly, or recklessly, indifferent whether it is a beach or not". ${ }^{91}$ Noting this, Bagshaw plausibly concludes: ${ }^{92}$

${ }^{87}$ Tort Law (4th edn.), 471-472.

${ }^{88}$ Suppose that D fires his rifle, aiming to hit his enemy, P, in the distance. D can intend to kill $\mathrm{P}$ notwithstanding that, at that range, his likelihood of succeeding is low.

89 Another way of putting this division is that the purposes, or ends, for which D acts are the reasons why one acts. They motivate and explain D's action. Intention embraces both these and the intermediate steps (the means) that D undertakes in order to achieve those ends. Sideeffects are those outcomes that, whether or not foreseen by D, did not motivate him to act as he did. See Finnis, supra n. 69, at pp. 229ff; Finnis, "Intention and side-effects" in R.G. Frey and C.W. Morris (eds.), Liability and Responsibility (Cambridge 1991) 32; A.P. Simester and Winnie Chan, "Intention Thus Far" [1997] Crim. L.R. 704.

90 (1853) 2 E. \& B. 216, 118 E.R. 749.

${ }^{91}$ [1966] 1 W.L.R. 691, 701. Cf. J.G. Fleming, The Law of Torts (9th edn., Sydney 1998), 762: in the context of inducing a breach of contract, "[i]ndifference is equated with intent".

92 Above note 65 , at p. 142 . Wedderburn also suggests that recklessness is sufficient: A.M. Dugdale (gen. ed.), Clerk and Lindsell on Torts (18th edn., London 2000), § 24-20. But the 
Thus it seems that the required mental state for the tort of procuring breach of contract is a sufficient degree of knowledge of the likelihood that conduct may bring about a breach of contract, and a choice to persist with that conduct despite the knowledge.

Bagshaw's analysis abandons the orthodox insistence on intention, favouring an advertent-recklessness standard. But that still leaves open the question of what degree of foresight is "sufficient". Presumably it would not be enough for D merely to suspect or recognise that there might exist a contract that is inconsistent with D's offer to C. Arguably, neither should it suffice if D recognises there is a significant albeit unintended risk that his conduct will induce $\mathrm{C}$ to breach a contract. Part of the reason is consequential. Liability for foreseen side-effects has the potential to restrict genuine competition and also to hinder the ability of parties to take action in disputes (for fear of putting the other party in breach of downstream contracts): ${ }^{93}$

Interference with contracts may flow from competition and is the normal and expected consequence of industrial action. It would not be right for the law to discourage competition by encouraging actions by unsuccessful competitors or to allow tort actions by those who suffer only incidentally from another person's activities.

These concerns about broadening the tort too far into recklessness have even led some writers to suggest that D must also be shown to have intended to harm $P$; or that D's persuasive actions must in some way have been "directed at" $\mathrm{P} .{ }^{94}$ Yet inducing breach of contract is designed to protect P's contractual rights. Hence it would seem sufficient for the contractual wrong to be intended, and

case that both Bagshaw (at $141 \mathrm{n}$. 31) and Wedderburn (at n. 14) cite in support of that conclusion does not, in fact, do so. Emerald Construction Co. Ltd. v. Lowthian [1966] 1 W.L.R. 691 is a case where D sought (that is, intended) termination, by breach if necessary. It is thus a case of conditional intention to procure a breach, not one of recklessness. The judgment of Diplock L.J. makes this clear (at 704): "ignorance of the precise terms of the contract is not enough to show absence of intent to procure its breach. The element of intent needed to constitute the tort of unlawful procurement of a breach of contract is, in my view, sufficiently established if it be proved that the defendants intended the party procured to bring the contract to an end by breach of it if there were no way of bringing it to an end lawfully. A defendant who acts with such intent runs the risk that if the contract is broken as a result of the party acting in the manner in which he is procured to act by the defendant, the defendant will be liable in damages to the other party to the contract". Compare Rickless v. United Artists [1986] F.S.R. 502 (in particular, the final paragraph from the unreported portion of the judgment by Hobhouse J.).

93 Millar v. Bassey [1994] E.M.L.R. 44, 64 (Peter Gibson L.J.). Compare K.W. Wedderburn, "Inducing Breach of Contract and Unlawful Interference with Trade" (1968) 31 M.L.R. 440, 445: "the flood of liability would engulf not only trade union officials but also the most innocent, competitive, profit-seeking trader".

94 E.g., Weir, above note 4, at p. 13. 
unnecessary to show the intent further to harm $\mathrm{P} .{ }^{95}$ That is no part of the paradigm case above; moreover, the authorities are clear that the presence or absence of malice (toward P) is irrelevant. ${ }^{96}$

In sum: partly because of the failure to separate prevention from persuasion, the mental elements required for inducing breach of contract are doctrinally uncertain and normatively controversial.

Our analysis of the wrongs involved in inducing breaches of contract offers tools with which to approach this problem. Let us first turn our attention away from consequential concerns such as the incentives to free competition, and focus on the relation of intention to the wrongness of D's action. Distinguishing between intended and foreseen interferences with contract is not merely a matter of consequences, and of balancing the harm to P against D's freedom of action. In both varieties of inducing breach of contract, the intention with which D acts is integral to the wrong that makes $\mathrm{D}$ responsible for the harm that $\mathrm{P}$ suffers.

Consider prevention. In the paradigm case, $\mathrm{D}$ wrongs $\mathrm{C}$ by an unlawful act, which in turn causes adverse consequences for $\mathrm{P}$. If we disregard D's intention, prima facie D owes no duty to P: the wrong is done to C. Typically, C may sue D for foreseeable losses caused by the unlawful act; her claim in tort is predicated upon the unlawful act itself, and contractual losses suffered by $\mathrm{C}$ are recoverable as tort losses in so far as they are foreseeable consequences of and not too remote from that unlawful act. By contrast, $\mathrm{P}$ has no standing to sue in the unlawful-act tort: he is not wronged by it.

What wrongs $\mathrm{P}$, and brings the further tort of inducing breach of contract into play, is that the unlawful act against $\mathrm{C}$ is committed - C's plight is created and used-in order to harm $P$, by depriving him of something to which he has a contractual right. It is the intention with which $\mathrm{D}$ acts that makes his conduct properly described as a (wrongful) attack on P. This is typical of economic wrongs. In a broadly free market, persons are left alone to pursue their own interests. In so doing, they wrong no-one even if their self-advancing conduct has deleterious side-effects for others. Sideeffects are a natural feature of competitive interaction: if I tender successfully for a contract, I may know that in so doing I will

95 As Beldam L.J. pointed out in Millar v. Bassey [1994] E.M.L.R. 44, 51, "[i]t was not alleged ... in Lumley v. Gye that the defendant Gye had any intention to cause harm to the plaintiff beyond an intention that Miss Wagner should break her contract with him". See also Edwin Hill \& Partners v. First National Finance Corp. [1989] 1 W.L.R. 225, 234 (Stuart-Smith L.J.), citing Smithies v. National Association of Operative Plasterers [1909] 1 K.B. 310, 316; South Wales Miners' Federation v. Glamorgan Coal Co. [1905] A.C. 239, 244 (Earl of Halsbury L.C.), 246 (Lord Macnaghten). Of course, whether or not intended, actual loss will be required for P to be awarded damages.

96 Cf. Quinn v. Leathem [1901] A.C. 495, 510 (Lord Macnaghten). 
deprive others of that contract and, in turn, weaken their commercial viability, cause employees to be laid off, etc. I do no wrong unless my bid is tendered in order to bring those consequences about; in which case I am no longer pursuing my own interests but, instead, am attacking the interests of others. That is morally wrongful even if I am attacking the interests of others only as a means, ultimately, to advance my own interests (a characteristic of wrongs such as dumping). Similarly, exploitationbased wrongs depend on the fact that the defendant acts as she does in order to take advantage of another's weaker position. Suppose that I price a good for sale at an unexpectedly high level. To do so discloses no wrong if I am simply a reluctant sellerperhaps the thing has sentimental value, or I know of another person willing to pay a high price for it. But if my reasons for asking a high price are that I know the buyer has desperate personal need for the good, my action may become a wrong.

As it happens, this constitutive role for intention is not confined to the marketplace. We noted earlier that a judge who sentences a criminal to jail may know that, in so doing, she will cause him to lose his job and bring hardship upon his family. But she does no wrong unless she sentences him in order to bring those outcomes about. Patriotic support for one's own team is acceptable, even if it gives the team a home advantage; supporting one's team by booing the opposition is not, notwithstanding that it may produce an identical advantageous consequence. The point is most famously articulated by Kant. It is ipso facto wrong to treat other persons as a means to advance one's own preferences. We do that when we intend harm to others; not when we seek a benefit in circumstances where adverse consequences occur just as side-effects.

None of this is to deny that there are occasions where I can wrong another person by harming her unintentionally-indeed, that possibility underpins the tort of negligence. But the wrong in such cases rests, in part, on a direct injury to the plaintiff's person or property. In contrast, a victim's economic interests are by their nature exposed to the adverse effects of others' economic activity: there is no general duty to avoid injury to economic interests and the mere fact that those interests are harmed cannot establish that D's act wrongs the victim. This distinction is buttressed by the consequential arguments, noted earlier, concerning the need not to restrict public economic activity by extending liability to foreseen side-effects, and thereby hindering market competition and dispute resolution through industrial action.

So it seems right that the tort committed when D prevents performance of C's contractual obligations should require an 
intention on D's part to harm $\mathrm{P} .{ }^{97}$ In prevention cases, D seeks to harm $\mathrm{P}$ by depriving him of something to which he has a right. That intention, addressed to $\mathrm{P}$, combines with the unlawful act, against $\mathrm{C}$, to constitute a wrong against $\mathrm{P}$ where the harm to $\mathrm{P}$, by itself, is insufficient.

What of inducing breach by persuasion? In persuasion, we have seen that the wrong to $\mathrm{P}$ does not rest on a requirement that $\mathrm{D}$ acted in order to harm $\mathrm{P}$. It rests on D's acting either to induce C to break her promise or to induce $\mathrm{C}$ to rethink her promise to $\mathrm{P}$ to not treat her promise as the promise it is. These, then, are the features of the tort that the mental element must reflect: it follows that it is sufficient, but not necessary, to satisfy the mental element if $\mathrm{D}$ intends $\mathrm{C}$ should breach her contract. Consider the following example:

Jane has promised to give $£ 100$ to charity K. I know that she made the promise impulsively, without considering the merits of alternative charities. I offer partially to subsidise Jane's gift if, as I urge, she will rethink her promise and instead give the money to the charity that, upon reflection, she decides is the most deserving; which may still be charity $\mathrm{K}$. Jane thinks about my offer but decides to stand by her original promise.

This is an example where I intentionally undermine the status of Jane's promise as a pre-emptive reason, without intending, ultimately, that she should break that promise. Correspondingly, while an intent to bring about non-performance is sufficient, ${ }^{98}$ it is not necessary. The mental element of inducing breach of contract by persuasion requires only that $\mathrm{D}$ seeks to undermine the status of C's promise as a pre-emptive reason. As cases like Lumley v. Gye demonstrate, there is no requirement that $\mathrm{D}$ acts in order to bring about harm to $\mathrm{P}$ or even in order to bring about a breach of contract. Rather, D seeks a response by $\mathrm{C}$ that, as D knows, involves and requires a reconsideration of C's promise to $\mathrm{P}$. As such, the reconsideration of C's promise is not a side-effect. It is an inseparable means: a step in the reasoning through which $\mathrm{C}$ must pass before accepting D's offer.

We see, then, that the often-cited formula, in which there must be "knowledge of the contract and the intention of bringing about its breach", 99 accurately describes neither prevention nor

${ }^{97}$ Both Falconer v. ASLEF [1986] I.R.L.R. 331 and Millar v. Bassey [1994] E.M.L.R. 44 should be doubted for this reason.

${ }^{98}$ For an example of the sufficient case, where non-performance itself is intended, suppose that C agrees to sell an old clock to P. D then persuades C to keep the clock because it is a family heirloom. D's intervention is not aimed at harming P, but it is a straightforward case of inducing breach of contract because $\mathrm{D}$ intends to induce $\mathrm{P}$ not to do what she promised.

99 Above note 86. 
persuasion. Prevention requires an intention to harm $\mathrm{P}$, by preventing $\mathrm{C}$ from performing. The mental element of persuasion is satisfied by either knowledge that what $\mathrm{D}$ encourages is inconsistent with C's promise to $\mathrm{P}$ or an intention that $\mathrm{C}$ should not perform as promised. In neither variety is recklessness sufficient. D's duties to $\mathrm{P}$ simply do not extend that far. In the economic torts, the distinction between incidental and intended harms is critical. It is right that D should not be permitted to attack P's contract with C. But it goes too far, and curtails D's freedom of action too greatly, that $\mathrm{D}$ should not be permitted to do anything that might undermine P's rights against $\mathrm{C}$.

\section{Persuasion and Advice}

This same analysis can help to illuminate quarrels about what forms of behaviour count as persuasion. Some commentators, for example, assert a distinction between persuasion and advice, with only persuasion being actionable. ${ }^{100}$ In general, those commentators seek to draw the distinction by reference to objective features of the D's conduct: did he create a reason to break a contract or did he "merely" point out a reason that already existed? ${ }^{101}$ But that account of the difference looks incomplete, since ordinarily one can "persuade" another to do something without having to create new reasons for doing it: indeed, that is the marque of good argument. At a deeper level, the account fails because it neglects the intentional nature of persuasion. Although there are defective varieties of persuasive action, in which one can fortuitously convince another of a proposition, persuasion is characteristically an intentional action. Hence it seems to us that the key question is, what were D's reasons for giving the advice? ${ }^{102}$ If $\mathrm{D}$ intended thereby to bring about a reconsideration of C's promise, there seems no reason why $\mathrm{D}$ should evade prima facie liability for inducing breach of contract, ${ }^{103}$ subject to any justificatory defence that may be available. On the other hand, if D's advice is genuinely disinterested, and he is simply pointing out relevant considerations without aiming to bring $\mathrm{C}$ to reconsider her promise, ${ }^{104}$ or indeed if

\footnotetext{
${ }^{100}$ R.A. Buckley and R. Heuston, Salmond and Heuston on the Law of Torts (21st edn., London 1996), 352; H. Carty, An Analysis of the Economic Torts (Oxford 2001), 47. Cf. D.C. Thomson \& Co. Ltd. v. Deakin [1952] Ch. 646, 686 (Evershed M.R.); Middlebrook Mushrooms Ltd. v. TGWU [1993] I.C.R. 612, 626 (Hoffmann L.J.).

${ }^{101}$ Cf. H.L.A. Hart and T. Honoré, Causation in the Law (2nd edn., Oxford 1985), 54.

102 Cf. Square Grip Reinforcement Co. Ltd. v. Macdonald [1968] S.L.T. 65, 73 (col. 2).

${ }^{103}$ As Winn L.J. thought in Torquay Hotel v. Cousins [1969] 2 Ch. 106, 147. So, too, Simonds J. in Camden Nominees Ltd. v. Forcey [1940] Ch. 352, 366: "[a]dvice which is intended to have persuasive effects is not distinguishable from inducement". Analogously, even a silent picket may, because of the intention of the picketers, be persuasion: Union Traffic Ltd. v. TGWU [1989] I.R.L.R. 127, C.A

104 Cf. D.C. Thomson \& Co. Ltd. v. Deakin [1952] Ch. 646, 686 (Evershed M.R.).
} 
C has already determined to break her contract and comes to D seeking advice, ${ }^{105} \mathrm{D}$ may plausibly lack the element of intention necessary to make his response a wrong to $\mathrm{P}$.

\section{Indirect versus Direct Prevention}

One remaining doctrinal quarrel goes to the heart of our thesis. There is authority in English law for drawing a distinction between direct and indirect prevention. As such, inducing breach of contract has the potential to be subdivided across three paradigms: persuasion, direct prevention, and indirect prevention. ${ }^{106}$ Recall the case set out at the commencement of this paper:

Case 2 (prevention): C2, a car manufacturer, has contracted with P2, a tyre manufacturer, to display P2's tyres on C2's cars while the cars are being exhibited at a motor show. During the show D2, a rival, removes P2's tyres without permission and replaces them with its own.

That is a paradigm of direct prevention of performance, where D physically prevents $\mathrm{C}$ from performing her contractual obligations. ${ }^{107}$ We can supplement that case with two further instances:

Case 3 (unlawful "indirect" prevention): C3, a manufacturer of machinery parts, has contracted with P3 to supply parts by a certain date. Near to that date D3 persuades E, and other employees of $\mathrm{C} 3$, to go on strike without giving proper notice. As intended, the strike prevents $\mathrm{C} 3$ from fulfilling its contract with P3.

Case 4 (lawful "indirect" prevention): C4 contracts to supply widgets to P4. D4 subsequently buys up all the widgets available in the marketplace, which as D4 knows will put C4 in a position where she is unable to perform her contract with P4.

The existence of three possible categories has caused some confusion in the case law, and considerable disagreement amongst commentators, about how the categories should be assimilated or differentiated. It is generally agreed that Case 4 discloses no cause of action, ${ }^{108}$ in the absence of unlawful means. But what marks

105 Cf. Board of Broadview School Unit No. 18 v. Saskatchewan Teachers Federation (1972) 32 D.L.R. (3d) 33; Long v. Smithson (1918) 88 L.J.K.B. 223. See also CBS Songs v. Amstrad Consumer Electronics plc [1988] A.C. 1013, 1058 (Lord Templeman); approved in Credit Lyonnais Bank Nederland v. Export Credits Guarantee Dept [2000] 1 A.C. 486, 499 (Lord Woolf M.R.).

106 D.C. Thomson \& Co. Ltd. v. Deakin [1952] Ch. 646, 681-682 (Evershed M.R.), 694-697 (Jenkins L.J.); Torquay Hotel Ltd. v. Cousins [1969] 2 Ch. 106, 138.

107 See D.C. Thomson \& Co. Ltd. v. Deakin [1952] Ch. 646, 695-696, 702 (Jenkins L.J.); also GWK Ltd. v. Dunlop Rubber Co. (1926) 42 T.L.R. 376.

108 Even by Lord Denning: Torquay Hotel v. Cousins [1969] 2 Ch. 106, 138: "[i]ndirect interference is only unlawful if unlawful means are used" (italics omitted); D.C. Thomson \& Co. Ltd. v. Deakin [1952] Ch. 646, 679-680 (Evershed M.R.), 696-698 (Jenkins L.J.). 
Case 4 apart? Does unlawfulness become requisite primarily because the case involves indirect prevention, or because it involves prevention rather than persuasion? These questions reflect an underlying categorisation issue for legal doctrine: should direct prevention (Case 2) be assimilated to (Case 1) persuasion, which might also be thought of as direct, or should it be assimilated to (Case 3) indirect prevention? Another way of putting this is to ask whether, instead of distinguishing between persuasion and prevention, we should be distinguishing between direct intervention (by persuasion or direct prevention) and indirect intervention (i.e., indirect prevention).

If the argument in this paper is correct, the basic distinction is that between persuasion and prevention-between inducing nonperformance through the medium of C's intervening choice and causing non-performance without C's cooperation. Hence, direct and indirect prevention should be treated together as instances of the general tort of deliberately causing harm by unlawful means and, as such, governed by the same set of doctrinal requirements, subject-in the normal way-to the standard constraints of remoteness that apply whenever someone commits a tort through the agency of another person. Notice, in particular, that those remoteness constraints are not specific to the prevention tort. They apply to all torts, including even inducing breach of contract by persuasion (should D use an intermediary to persuade C). There is, in other words, nothing special about "indirect" prevention.

The point is controversial, partly because the cases frequently describe persuasion as a form of "direct" intervention. ${ }^{109}$ Thus some writers have argued that it is the direct/indirect dichotomy that is decisive; on their view, directly preventing performance is like persuading $\mathrm{C}$ to breach, and therefore subject to the same doctrinal requirements that apply to inducement by persuasion. McBride and Bagshaw, for example, assert that: ${ }^{10}$

If $\mathrm{D}$ has performed an act which directly prevented $\mathrm{T}$ from performing his contract with $\mathrm{V}$ then $\mathrm{D}$ will have induced $\mathrm{T}$ to breach his contract with V.... So suppose T contractually agreed to sing for $\mathrm{V}$ one evening and $\mathrm{D}$ tied her up so that she could not perform for $\mathrm{V}$. Now if $\mathrm{D}$ acted in order to harm V, $\mathrm{V}$ will be able to sue $\mathrm{D}$ on the basis that $\mathrm{D}$ committed the tort of using unlawful means to harm another in relation to $\mathrm{V}$ in acting as he did. But even if $\mathrm{D}$ did not try to harm $\mathrm{V}$ in acting

${ }^{109}$ See, e.g., D.C. Thomson \& Co. Ltd. v. Deakin [1952] Ch. 646, 694, 702 (Jenkins L.J.); Torquay Hotel v. Cousins [1969] 2 Ch. 106, 138 (Lord Denning).

110 N.J. McBride and R Bagshaw, Tort Law (London 2001), 333 (emphasis in original). The authors' claim that $\mathrm{D}$ will have induced a breach of contract is subject to the usual provisos about D's mental element and possible justifications. See also J.D. Heydon, Economic Torts (2nd edn., London 1978), 29, 31. 
as he did, $\mathrm{V}$ will still be able to establish that $\mathrm{D}$ committed the tort of inducing breach of contract.... In contrast, if $\mathrm{D}$ has indirectly prevented $\mathrm{T}$ from performing a contract with $\mathrm{V}, \mathrm{V}$ will not be able to establish that $\mathrm{D}$ committed the tort of inducing breach of contract ... and so if $\mathrm{V}$ wants to sue $\mathrm{D}, \mathrm{V}$ will have to establish that $\mathrm{D}$ committed the tort of using unlawful means to harm another in acting as he did and will therefore have to establish that $\mathrm{D}$ used unlawful means to prevent $\mathrm{T}$ from performing his contract and that $\mathrm{D}$ acted as he did with the aim of harming $\mathrm{V}$.

There are a number of reasons for thinking this analysis should not be preferred. First, it would mean that in the case of direct prevention, D's act need not be unlawful (curiously, this is concealed by McBride and Bagshaw's example). Suppose, then, a scenario in which $\mathrm{C}$ has agreed to sing for $\mathrm{P}$ and needs, now, to get to the theatre. However, her car is misparked and D lawfully clamps it; thereby, as $\mathrm{D}$ knows, preventing $\mathrm{C}$ from getting to the theatre and putting her in breach of contract. Allen v. Flood governs this case. ${ }^{111}$ As we observed earlier, in the absence of an unlawful means, D is not and should not be liable to $\mathrm{P}$ for causing $\mathrm{C}$ to breach her contract. Direct prevention by a lawful act cannot be assimilated with persuasion. ${ }^{112}$

Of course, it may be argued that, at least where $\mathrm{D}$ intends to harm $\mathrm{P}$ by preventing C's performance, tort law ought to allow a remedy notwithstanding Allen v. Flood. ${ }^{113}$ But the making of that argument turns upon the fact that $\mathrm{D}$ intends harm to $\mathrm{P}$ : hence, it is properly an argument about the restricted scope of the tort of deliberately causing loss (by unlawful means), and whether current law should be widened into a prima facie tort of intentionally inflicting harm, as has sometimes been suggested in the United States. ${ }^{114}$ The mens rea of such a tort is clearly more stringent than is required to satisfy inducing breach of contract by persuasion. And so it should be: in the absence of intention to harm, going about one's own business, while realising that one's lawful conduct

111 [1898] A.C. 1; above notes 33, 57. See also D.C. Thomson \& Co. Ltd. v. Deakin [1952] Ch. 646, 693 (Evershed M.R.), quoted above in the text at n. 31. Or suppose that C has contracted to sell an asset to P. C is deeply in debt to D, who forces $\mathrm{C}$ into bankruptcy in order to prevent transfer of the asset.

112 Heydon (above note 110) cites Esso Petroleum Co. Ltd. v. Kingswood Motors (Addlestone) Ltd. [1974] 1 Q.B. 142 as authority that direct prevention can be a tort even when the means are lawful. But Esso v. Kingswood does not support his analysis, since in that case D (also a company) was the owner of $\mathrm{C}$ and the case is thus not accurately depicted as one of "prevention" by a third party. Moreover, the means used were in any event identified by Bridge J. (at 155-156) as unlawful, since they constituted a civil conspiracy to induce a breach of contract.

${ }^{113}$ Finnis, above note 69.

${ }^{114}$ For an interesting study of the American experience and the issues it raises, see C. Witting, "Of Principle and Prima Facie Tort" (1999) 25 Monash U.L.R. 295. 
will have adverse economic impacts on others, should not be the stuff of tort. ${ }^{115}$

Further, the proposed analysis makes too much turn on the direct/indirect distinction, a distinction that, as drawn in this context, is at best unstable and at worst incoherent. ${ }^{116}$ The informing idea behind the distinction seems to be that direct intervention requires no active human intervention to supply the conduit between D and non-performance of the contract. ${ }^{117}$ Hence, when D ties C up and prevents her from singing, his intervention is direct. And when $\mathrm{D}$ persuades $\mathrm{E}$ to go on strike and thereby prevent $\mathrm{C}$ from fulfilling its contract, his intervention is indirect since it requires a further act by $\mathrm{E}$. Bagshaw buttresses this analytic dichotomy with a normative rationale: ${ }^{18}$

If this version of the distinction is accepted then the reason for imposing, or at least considering imposing, different standards of liability in the indirect form is clear: We require special reasons for making me responsible for the consequences of the behaviour of another.

The normative point is true enough. Indeed, it is one of the reasons why inducing breach of contract is philosophically so complex. But its application does not track the direct/indirect distinction in the way that Bagshaw expects. On a normative analysis, the case of persuasion would be indirect not direct intervention: ${ }^{119}$ it requires a further intervening act by $\mathrm{C}$ before $\mathrm{P}$ is deprived of performance. Conversely, on the same analysis, buying up all the widgets and thereby preventing $\mathrm{C}$ from fulfilling her supply agreement is direct prevention-it requires no further actions by anyone to make performance impossible. It is not obvious how, causally speaking, this is any less direct a mode of prevention than is removing all the car tyres, or indeed tying $\mathrm{C}$ up-what distinguishes the latter cases is, rather, that the means in each is illegal. As conventionally drawn, the direct/indirect dichotomy lacks moral significance. It offers no moral tools of its own with which to differentiate the various scenarios that we loosely call inducing breach of contract. By contrast, we have argued in this paper that the persuasion/ prevention distinction is both analytically intelligible and morally profound.

\footnotetext{
115 See the text above at pp. 157-8.

116 As Weir argues: A Casebook on Tort (9th edn., London 2000), 606.

117 Bagshaw, supra n. 65, at p. 148; "the most obvious way of drawing [the direct/indirect distinction] is to ask whether the interference occurred through the acts or omissions or some human agent interposed between the defendant and the contract". For alternative accounts, offered without normative underpinnings, see Greig v. Insole [1978] 1 W.L.R. 302, 334 (Slade J.) and Middlebrook Mushrooms Ltd. v. TGWU [1993] I.C.R. 612, 625 (Hoffmann L.J.).

118 Bagshaw, above note 65, at p. 148.

119 Contra Bagshaw, ibid.
} 


\section{CONCLUSION}

We have not sought, in this paper, to resolve every issue to which inducing breach of contract gives rise. Neither have we sought to explain all the boundaries of the tort, or to reconcile every case. Our concern has been with the central cases, with the heart of the tort, because it is only when the paradigm cases and their structural core are understood that we can begin to assess the difficult, borderline, cases that now populate the reports. We have argued that inducing breach of contract by persuasion is a different tort, with differing legal criteria, from inducing non-performance by prevention. In persuasion cases, $\mathrm{D}$ is held co-responsible for the breach of contract that $\mathrm{C}$ chooses to commit. In prevention cases, direct or indirect, no such choice is made by $\mathrm{C}$; D simply brings about non-performance without reference to the wills of the contracting parties. Indeed, although each is conventionally regarded as a species of inducing breach of contract, the prevention tort is in truth a species of the more general tort of deliberately causing loss by unlawful means. Be that as it may, we have argued that the differing criteria and underlying rationales are not in conflict. The two paradigms with which we began this paper capture separate cases where state intervention can be justified. Both causes of actions lie properly within a plaintiff's armoury.

\section{CAmbridge JULNALS}

